
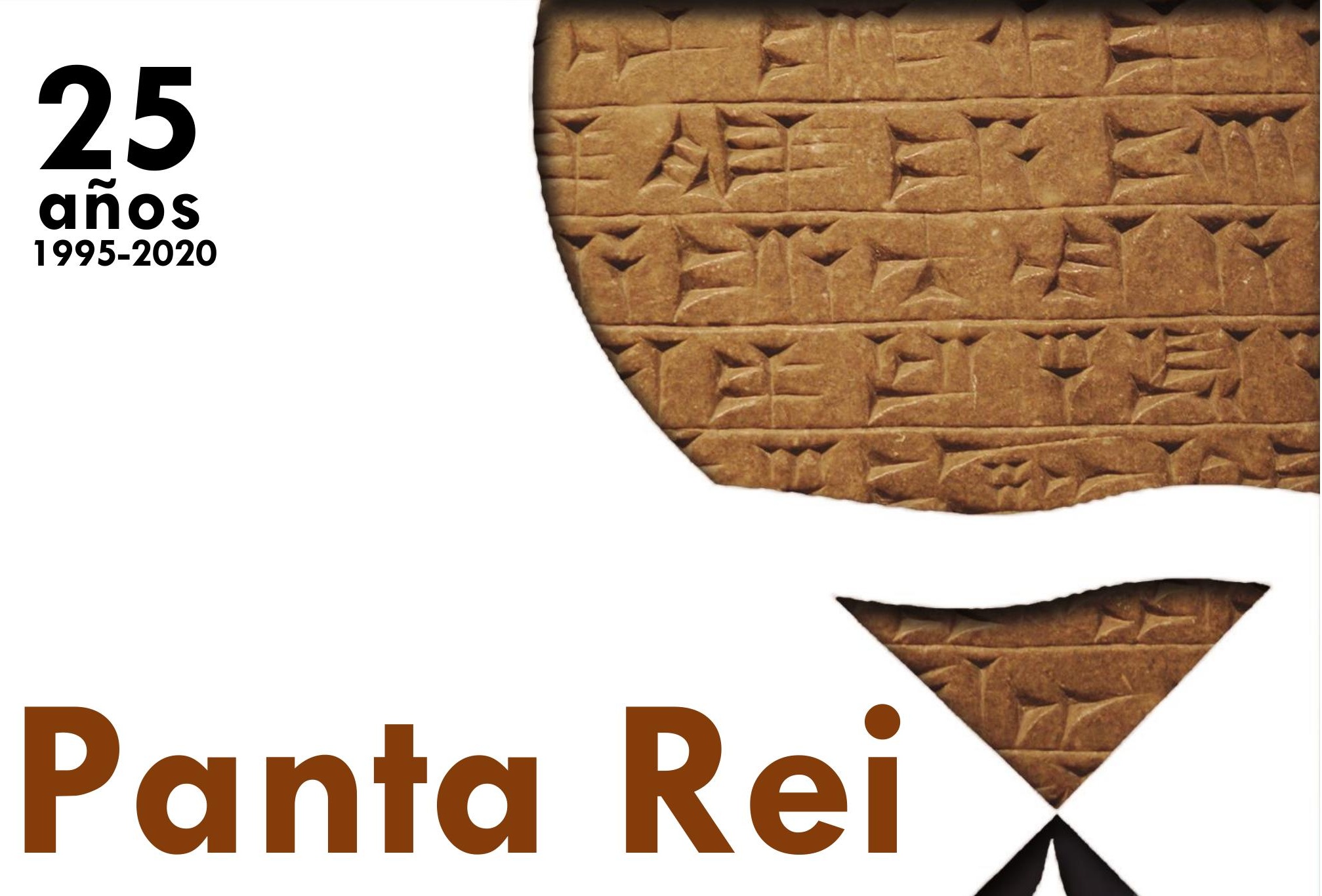

Revista digital de Historia y didáctica de la Historia 


\section{0 (2)}

Revista anual

Fecha de inicio: 1995

Revista Panta Rei. pantarei@um.es

\section{Edita:}

Centro de Estudios del Próximo Oriente y la Antigüedad Tardía - CEPOAT

Edificio Universitario Saavedra Fajardo.

Universidad de Murcia

C/ Actor Isidoro Máiquez, 9

30007 - MURCIA - ESPAÑA

Teléfono: $(+34) 868883890$

cepoat@um.es

Web: www.um.es/cepoat/pantarei

Ediciones de la Universidad de Murcia - EDITUM

Edificio Pleiades. Campus de Espinardo.

Universidad de Murcia

C/ Campus, s/n

30100 - MURCIA - ESPAÑA

Teléfono: $(+34) 868883013$

editum@um.es

Web: https://www.um.es/web/editum/

En portada: Montaje elaborado a partir de fotografía de una inscripción sumeria del British Museum (Wikimedia) (arriba) y fotografía de Miguel Martínez Sánchez (abajo)

Edición 2020 (2)

ISSNe: 2386-8864

ISSN: $1136-2464$
Responsables de los textos: sus autores.

Responsable de la presente edición: Consejo Editorial de Panta Rei.

Depósito legal: MU-966-1995 


\section{CONSEJO DE REDACCIÓN}

Coordinador editorial

Egea Vivancos, Alejandro [Didáctica de las Ciencias Sociales, Universidad de Murcia]

Secretaria

Arias Ferrer, Laura [Didáctica de las Ciencias

Sociales, Universidad de Murcia]

Editores

Jiménez Vialás, Helena [Historia Antigua, Universidad de Murcia]

Martínez Gil, Tània [Didáctica de las Ciencias

Sociales, Universidad de Barcelona]

Meseguer Gil, Antonio José [Historiador, Profesor de

Secundaria]

Ortiz García, Jónatan [Arqueología, Universidad de

Alcalá de Henares]

Romero Molero, Alberto [Arqueología, Universidad

Isabel I]

Sáez Giménez, David Omar [Historiador, Profesor

de Secundaria]

Sáez Rosenkranz, Isidora V. [Didáctica de las

Ciencias Sociales, Universidad de Barcelona]

Sánchez Mondejar, Celso Miguel [Arqueólogo,

Patrimonio Inteligente]

Responsable informático

Martínez García, José Javier [CEPOAT, Universidad de Murcia]

Responsables de traducción y corrección lingüística Martínez Martínez, Cristina [Profesora de Secundaria, Sociedad Española de Lenguas Modernas] Albaladejo Albaladejo, Sara [ISEN-Universidad de Murcia]

\section{CONSEJO ASESOR}

Adroher Auroux, Andrés María [Arqueología, Universidad de Granada]

Albero Muñoz, $M^{a}$ del Mar [H. ${ }^{a}$ del Arte, Universidad de Murcia]

Alia Miranda, Francisco [Historia Contemporánea, UCLM]

Arciniega García, Luis [Historia del Arte, Universidad de Valencia]

Barrio Barrio, Juan Antonio [Historia Medieval,

Universidad de Alicante]

Castellano i Solé, Núria [Egiptología, Schola

Didàctica Activa S.L.]

Chapman, Arthur [History Education, University

College of London, Reino Unido]

Cid López, Rosa María [Historia Antigua, Universidad de Oviedo]

Cobacho López, Ángel [Derecho, Universidad de Murcia]

Cuenca López, José María [Didáctica de las Ciencias Sociales, Universidad de Huelva]
Egea Bruno, Pedro M. ${ }^{a}$ [Historia Contemporánea, Universidad de Murcia]

Feijoo Martínez, Santiago [Arqueología, Consorcio

Ciudad Monumental de Mérida]

García Atienzar, Gabriel [Prehistoria, Universidad de

Alicante]

Ginestí Rosell, Anna [Filología Clásica, Katholische

Universität Eichstätt-Ingolstadt]

González Monfort, Neus [Didáctica de las

Ciencias Sociales, Universidad Autónoma de

Barcelona]

González Soutelo, Silvia [Arqueología, Universidad de Vigo]

Haber Uriarte, María [Prehistoria, Universidad de Murcia]

Hernández de la Fuente, David [Filología Clásica, Universidad Complutense]

Hutson, Scott R. [Anthropology, University of Kentucky, EEUU]

Igual Luis, David [Historia Medieval, UCLM]

Irigoyen López, Antonio [Historia Moderna,

Universidad de Murcia]

Jover Maestre, Francisco Javier [Prehistoria,

Universidad de Alicante]

Mahony, Simon [Digital Humanities, University College of London, Reino Unido]

Marsilla de Pascual, Francisco Reyes [Técnicas

historiográficas, Universidad de Murcia]

Martínez-Burgos García, Palma [H. ${ }^{a}$ del Arte, UCLM]

Mathis, Christian [Didaktik der Geschichte, PH Zürich]

Miralles Maldonado, José Carlos [Filología Clásica,

Universidad de Murcia]

Molina Gómez, José Antonio [Historia Antigua,

Universidad de Murcia]

Mónica Ghirardi [Historia Moderna, Universidad

Nacional de Córdoba, Argentina]

Navarro Espinach, Germán [Historia Medieval,

Universidad de Zaragoza]

Noguera Celdrán, José Miguel [Arqueología,

Universidad de Murcia]

Ortiz Heras, Manuel [Historia Contemporánea, UCLM]

Panzram, Sabine [Historia Antigua, Universität

Hamburg]

Pérez Molina, Miguel Emilio [Filología Clásica,

Universidad de Murcia]

Prados Martínez, Fernando [Arqueología,

Universidad de Alicante]

Sánchez lbáñez, Raquel [Didáctica de las Ciencias

Sociales, Universidad de Murcia]

Sancho Gómez, Miguel Pablo [Educación, UCAM]

Victoria Moreno, Diego [Historia Contemporánea,

UNED]

Vilar García, María José [Historia Contemporánea,

Universidad de Murcia]

Vivas Sainz, Inmaculada [H. ${ }^{a}$ del Arte, UNED]

Zamora López, José Ángel [Próximo Oriente Antiguo,

CCHS-CSIC] 



\section{Índice}

1995-2020. 25 años de Panta Rei

Equipo editorial

La Historia social aplicada a la antigua Mesopotamia: cambios historiográficos y nuevas vías de 9 investigación

Josué Javier Justel Vicente

A Look Back into Ancient Egyptian Linguistic Studies (c. 1995-2019)

Carlos Gracia Zamacona

La infancia en la antigua Mesopotamia: 25 años de investigación

Daniel Justel Vicente

Conflictos armados y su tratamiento en educación. Análisis de la producción científica de los últimos

25 años en la Web of Science

Naiara Vicent, Janire Castrillo, Alex Ibañez-Etxeberria y Leire Albas

La investigación en pensamiento histórico. Un estudio a través de las tesis doctorales de Ciencias

Sociales (1995-2020)

Álvaro Chaparro Sainz, M.a del Mar Felices de la Fuente y Laura Triviño Cabrera

Las narrativas nacionales en la enseñanza y el aprendizaje de la historia: Una revisión sobre los libros de texto y las narrativas de los estudiantes

César López Rodríguez

La historia de las personas: reflexiones desde la historiografía y de la didáctica de las ciencias sociales durante los últimos 25 años

Mariona Massip Sabater, Jordi Castellví Mata y Joan Pagès Blanch †

Panorámica de la trilogía cine, historia y educación en España (1995-2020) 



\title{
A Look Back into Ancient Egyptian Linguistic Studies (c. 1995-2019)
}

\section{Retrospectiva de los estudios lingüísticos sobre el egipcio antiguo}

\author{
(c. 1995-2019)
}

\author{
Carlos Gracia Zamacona \\ Universidad de Alcalá \\ carlos.gracia@uah.es \\ 0000-0003-2181-4663
}

Recibido: 23/12/2019

Aceptado: 06/06/2020

\begin{abstract}
This article provides a personal overview of the last 25-year linguistic research on ancient Egyptian, the language spoken and written in Egypt since the origin of the written Egyptian civilization (c. $3150 \mathrm{BC}$ ) until the disappearance of Coptic as a living language ( $17^{\text {th }}$ century $A C$ ), the longest-attested human language. With this purpose, the main theoretical approaches and their relationship to teaching ancient Egyptian at the university are reviewed. Through the analysis of the more relevant bibliography of the period, four productive research lines are discussed: form and function; documents and the language; lexicon and grammar; and ancient Egyptian metalinguistics. The article ends with a short comment on the need of more corpus-based studies in the future instead of theoreticallybased frameworks for interpreting the ancient Egyptian language.
\end{abstract}

\section{Keywords}

Middle Eastern Studies, Historiography, Bibliographies, Ancient History, Egyptology.

\section{Resumen}

En este artículo se propone una revisión personal de la investigación lingüistica de los últimos 25 años sobre el egipcio antiguo, la lengua hablada y escrita en Egipto desde el origen de la civilización egipcia escrita (hacia 3150 a. C.) hasta la desaparición del copto como lengua viva (siglo XVII d. C.), la lengua humana documentada durante más tiempo. Con este fin, se revisarán las principales corrientes teóricas y su relación con la enseñanza del antiguo egipcio en ámbito universitario. Mediante el análisis de la bibliografía más relevante de este periodo, se comentan cuatro líneas de investigación productivas: forma y función; documentos y lengua; léxico y gramática; y metalingüística en el Egipto antiguo. El artículo finaliza con un breve comentario sobre la necesidad de más estudios basados en corpora en el futuro, en lugar de los basados en marcos teóricos para la interpretación del egipcio antiguo.

\section{Palabras clave}

Estudios sobre Oriente Próximo, Historiografía, Bibliografía, Historia antigua, Egiptología. 


\section{Introduction}

The ancient Egyptian language is of the highest importance for linguistics and the history of human language, hence to the history of humankind.

Ancient Egyptian was spoken in Egypt since the beginning of the written record about $3150 \mathrm{BC}$ to the seventeenth century-very probably much longer before. Ancient Egyptian is also the longest-recorded language in the world: for more than five thousand years (since $3150 \mathrm{BC}$ to the present) ancient Egyptian has been written and read and still is because of Coptic, the last stage of Egyptian, which is the liturgic language of the Coptic Church.

For the linguist, this situation represents the possibility of tracing the written mark of a large amount of linguistic phenomena through centuries and broad geographical areas: (almost) all changes a language can undergo under the pressure of its use, from social and literary variations to diatopic and diachronic changes in lexicon, grammar and style, may find their place in ancient Egyptian.

It is, alas, a well-established fact that linguistics, as a discipline, has almost exclusively focused on "living" languages, i.e. languages with speaking informants, and has left apart "dead" languages, i.e. languages with no speaking informants. It is also a well-established fact that this bias in the linguistic research relies on the sharp division Ferdinand de Saussure (1916, chap. VI § 2) made between the spoken and the written, and his statement that only the first was the object of linguistic study.

Apart from the fact that this position was due to Saussure's need of marking a difference with the Biblical and Sanskrit philologies, and leaving apart the gigantic figure and fundamental contribution to the European knowledge of the Swiss master, Saussure's banning of the writing from the linguistic discipline was more for the lose than for the gain. This point has been revisited since on theoretical grounds for figures of not minor influence such as Ludwig Wittgenstein (1953) and Jacques Derrida (1967).

This brief article merely intends to bring the general audience's attention to the ancient Egyptian language as a linguistic study item. For recent linguistic presentations of ancient Egyptian and its major topics in depth, the reader is invited to consult essential works such as Loprieno (1995), Grossmann, Haspelmath and Richter (2015), and the series The Mouton Companions to Ancient Egyptian (since 2019), published by De Gruyter and edited by Eitan Grossman, Stéphane Polis and Jean Winand, are already available to the reader.

Notwithstanding the obvious relevance for linguistics of studying writing systems, the present study only discusses the work on exclusively the language, not the writing system of ancient Egypt during the last twenty-five years for three reasons.

The first one is practical: the impressive quantity of studies devoted to the ancient Egyptian writing system semiotic aspects in that period precludes of presenting an adjusted picture of the research done (a short presentation is Nyord, 2015).

The second reason is programmatic and addressed to the linguists: to show that the paramount importance of ancient Egyptian for linguistics critically relies on its recorded longevity. In this sense, written records are just evidence of phenomena highly relevant for linguistics. 
The third reason is also programmatic but this time addressed to the Egyptologists: the brilliance of the hieroglyphs has, since the beginning, inflamed the Western imagination. This bedazzlement has had a direct and broad impact into the practice of learning and teaching the Egyptian language as a matter subsidiary in some sort to the hieroglyphic writing system. This biased presentation of the relation between the ancient Egyptian language and the hieroglyphic writing system has obscured the fact that a language can be written in different scripts and that a script can write different languages, and springs from the prejudice that an alphabetic writing system is closer to the language than a non-alphabetic system. This situation is patent since the very beginning of the Western studies on ancient Egypt, whatever the scientific level: from ancient Horapollo to the present societies of the Pharaonic culture lovers passing by the eighteenth and nineteenth-century esoterism in popular culture; from classicists' prejudices on ancient Egypt as a "high culture" (Arnold, 1869), already present in the background of some Jean-François Champollion's letters commenting on the architecture (1829, p. 22-23 and 57) and still active (compare, for instance, the opposite views of Thornton, 2002; and Whitmarsh \& Thomson, 2013) to some biblists' "Coptic-is-Greek" reductionism (Oréal, 1999) in academic context.

Now that we are close to celebrate the bicentenary of the origin of Egyptology (2022), a short glimpse backwards can provide some context for the remarks in the next sections. In the collective volume to celebrate the first centenary of the decipherment of ancient Egyptian writing system by Champollion, the brilliant discovery that put Egyptology as a discipline into a start, Vladimir Golénischeff (1922, p. 685) wrote:

Malgré un siècle déjà écoulé, depuis que la géniale découverte de Champollion nous a entrouvert la porte de l'étude des textes égyptiens, et malgré les efforts incessants que les disciples de l'immortel fondateur de l'Égyptologie ont faits, à sa suite, pour pénétrer les mystères de la langue égyptienne, il y a encore dans la grammaire de cette langue pas mal de points qui restent peu clairs et qui jusqu'à ce jour n'ont pu être expliqués d'une manière satisfaisante. C'est surtout la syntaxe égyptienne qui n'a pas suffisamment attiré l'attention des égyptologues, et c'est sur ce domaine que s'est peut-être le plus manifestée l'influence néfaste de l'école égyptologique qui a pris à tâche de démontrer que la langue égyptienne était une langue sémitique et que les règles de grammaire des langues sémitiques pouvaient naturellement lui être appliquées.

Almost a century later, and despite the many improvements by outstanding scholars such as Battiscombe Gunn (1924), Alan Gardiner (1957, 1 st published 1927), Hans Jakob Polotsky (1944, 1965), Jacques-Jean Clère (1949), Elmar Edel (1954-1964), Gerhard Fecht (1960) or Jean-Louis de Cénival (1977), many issues are still to be ascertained: this time not from the viewpoint (Hagège, 1996) of syntax but the viewpoint of semantics and pragmatics; this time not to go further than the "Egyptian-is-a-Semitic-language" mainstream school in Golénischeff's times but further than the "One-form-one-meaning" mainstream school nowadays that starts with Polotsky's later studies (1976), and was hastily labelled "Standard Theory" by Leo Depuydt (1983). 


\section{Method}

What follows is a showcase of selected linguistic studies on ancient Egyptian language since 1995 to 2019. The criterium for selecting the studies has been precisely their determined purpose of advancing our knowledge of the Egyptian language beyond the limits that the present doxa has given to the "standard" research.

In particular, three galvanic works led this way before 1995, and have thus been taken here as precursors of the future research on the semantic and pragmatic points of view: Antonio Loprieno (1986), Friedrich Junge (1989) and Pascal Vernus (1990). Loprieno's and Vernus' contributions marked a new path into verbal semantics, showing how form and function are to be carefully distinguished as analytical categories. Loprieno demonstrated that perfective and prospective semantic verbal categories are formally linked in Egyptian and the Semitic languages through gram t. Vernus proved the grammaticalisation path of the formal pattern preposition + infinitive into the temporal function 'progressive' and 'future' depending on the prepositions employed and their adjusting into a system through its opposition, respectively, with the 'general imperfective' and the prospective. As for Junge, he opened the way to the pragmatic studies with his analysis of the communicative strategies to express emphasis in ancient Egyptian. The path that these three studies marked has been an essential criterium to selecting the works included in this article.

The data necessary for covering the selection of works have mainly been extracted from the following sources:

- The proceedings of specialized international conferences (mainly the series named "Crossroads");

- Some general reviews from the hand of specialists, even if previous to the earlier date of this review, including Assmann (1974), Polotsky (1987), Schenkel (1988), Junge (1991), Loprieno (1994, 2003).

- The specialized journal Lingua Aegyptia (since 1991); and

- The relevant entries (since 2013) from the UCLA Encyclopedia of Egyptology "Language, Text and Writing" area, which is edited by Julie Stauder-Porchet and Andréas Stauder.

Of these sources, international conferences best indicate to what extent semantic and pragmatic issues have found their place among the purely formal studies. This tendency is evident in Table 1 , in which the number of articles devoted to morphosyntax, semantics and pragmatics in these conference proceedings is displayed: 


\section{Table 1}

Conferences in ancient Egyptian language (by publication date of their proceedings)

\begin{tabular}{|c|c|c|c|c|}
\hline & \multicolumn{3}{|c|}{ Linguistic points of view } & \multirow{2}{*}{$\begin{array}{l}\text { Other } \\
\text { subjects }\end{array}$} \\
\hline & Morphosyntactic & Semantic & Pragmatic & \\
\hline $\begin{array}{l}\text { Crossroads I (Englund and } \\
\text { Frandsen, 1986) }\end{array}$ & 3 & 4 & 9 & \\
\hline Crossroads II (Loprieno, 1991) & 5 & 3 & 11 & \\
\hline $\begin{array}{l}\text { Crossroads III (Junge, Kammerzell } \\
\text { and Loprieno, 1994) }\end{array}$ & 6 & 3 & 6 & \\
\hline After Polotsky (Lepper, 2006) & 9 & 5 & 11 & \\
\hline $\begin{array}{l}\text { Crossroads IV (Müller and Ulias, } \\
\text { 2009) }\end{array}$ & 6 & 5 & 4 & \\
\hline $\begin{array}{l}\text { Lexical semantics (Grossman, Polis } \\
\text { and Winand, 2012) }\end{array}$ & 0 & 9 & 1 & 3 \\
\hline $\begin{array}{l}\text { On forms and functions (Grossman, } \\
\text { Polis, Stauder and Winand, 2014) }\end{array}$ & 3 & 4 & 3 & \\
\hline $\begin{array}{l}\text { Egyptian and Typology (Grossman, } \\
\text { Haspelmath and Richter, 2015) }\end{array}$ & 6 & 2 & 3 & \\
\hline $\begin{array}{l}\text { Coping with obscurity (Allen, Collier } \\
\text { and Stauder, 2016) }\end{array}$ & 4 & 2 & 3 & \\
\hline Crossroads V (Werning, 2017) & 8 & 2 & 1 & 1 \\
\hline Rethinking the Origins (2018) & 10 & 1 & 0 & \\
\hline
\end{tabular}

Source: Personal compilation.

This table displays that: one, the first reaction to the Standard Theory came mostly from pragmatics (1986-2006); two, semantic contributions (including those that are usually labelled as "cognitive linguistics") are minority, except for the volume on lexical semantics (2012) for obvious reasons, and the more balanced volumes in 2009 and 2014; three, last volumes attest to the growing of formal studies, especially Crossroads V (2016).

My criterium to assign these articles to the different categories can be disputed, indeed. Especially, some articles deal with semantic and pragmatic issues related to syntax. In most of those cases, I have considered the pragmatic elements more determining.

Notwithstanding this, table 1 gives a "gross", preliminary insight into the general tendency of research during the last years. In what follows, some specific research lines are discussed which I have considered more relevant for advancing the knowledge about ancient Egyptian language. 


\section{Discussion}

Four research questions have become central to recent studies on the ancient Egyptian language.

First is the dichotomy between form and function (3.1). Mainly due to the opacity of the ancient Egyptian writing system regarding morphology, how to establish the link between form and function has relied, at best, on contextual-based approaches or, at the worst, on speculative recreations. The question is still (and will be) central to the work of Egyptologists and linguists.

Second is the study of the relations between documents and the language (3.2). Deeply linked to the philological tradition, this kind of studies focuses quite naturally on the language as a tool to dating texts but also the other way around in providing a path to studies in historical grammar which have concentrated on grammaticalisation phenomena. This approach could be not free of circularity in that language is used to date texts and vice-versa. Even when the witnesses of a given text are archaeological or historically dated, the text dating is sometimes restricted to the text inscription on a given witness, not to the text itself, especially when it comes to texts of prestige such as literary and mortuary texts.

The third is the superseding of the grammar-lexicon dichotomy inherited from the mainstream formalist (structuralist-generativist) linguistics (3.3). This trend is the most promising and needed for studies. It requires a combinative approach of a large number of materials to take into account a vast range of metadata relating to the proper linguistic data, including spellings, linguistic context, textual context, communicative context, social context, among others, and, which is more important, how all these interlink to each other. It is not surprising thus if this trend has always been the most solitary (see section 2 and table 1)

Fourth is the Egyptologists' conscience of their own bias when studying ancient Egyptian (3.4). Although a minority, these approaches provide a new, necessary perspective to linguistic studies on ancient Egyptian and Egyptology as a discipline in the whole.

\subsection{Function and/or form}

That the term "Standard theory" for Polotsky's late developments was hastily coined in 1983, was made clear by some scholars already in the 80 s but most definitively since the $90 \mathrm{~s}$. While it is true that generations of Egyptologists were taught under the many editions of Wolfgang Schenkel's teaching handbook (since 1980; see Schenkel, 1991), and numerous inside-the-box articles were published in those years (Depuydt, 1994, 1995a,b, 1996), two major works were published in the 90 s that stressed a context-sensitive approach to the analysis of the central question of the verb forms: I am referring of course to Pascal Vernus' Future at issue (1990) and Les parties du discours en moyen égyptien (1997). Far from producing a handbook to ease the teaching of a too straightforward way of seeing ancient Egyptian (or any other human language in fact), i.e. one form for one function and vice-versa, Vernus stressed how forms, especially verbal forms, changed through time and contexts. That these changes had a direct impact in grammar became then proved: for instance, the grammaticalisation of the preposition + infinitive structures for "new" verbal forms (the progressive and future). These dynamic approaches were well attuned with influential linguistic works on grammaticalisation (Bybee, 1985; Bybee, Perkins \& Pagliuca, 1994; Traugott \& Heine, 1991) and text grammar (Biber, 1989), which were challenging the prevalent 
formalist approaches (structuralism and generativism). The first reaction in Egyptology was rejection (Satzinger \& Shisha Halevy, 1999); then, much more significantly, some dozens of "new grammars" were published (Mathieu, 2013, p. 439). This fact can be explained whether by the revulsive effect of the new approaches, by the docent duties of their authors, in need or in search of a specific model fit for teaching their students, on the other, or even by the urge of the new university cursus honorum on the scholars, especially in Europe resulting from the Bologna Process (see Gracia Zamacona fc.), or by all these factors together and perhaps even others.

The jump from the pioneering work in ancient Egyptian syntax by Gunn, Gardiner's grammar -himself a pioneer of linguistic pragmatics (Gardiner, 1951) unknown to the British school led by John Austin (1962)-, and the "Polotskyan revolution", to the study of the ancient Egyptian language through post-structuralist positions had been one of quality: It would not only cause a shift in the research subjects (see the next two sections) but a reaction on the studies of the linguistic form.

On syntax, classic structuralist studies like Ariel Shisha-Halevy's on Bohairic (2007) have been flanked by generativist approaches such as Christopher Reintges (1997), even by more idiosincratic, hyperformalist studies like those based on mathematical models (Depuydt 1999a\&b).

On morphology, several disparate studies have been proposed on mainly formal grounds to discuss the number, origin and meaning of verbal forms (Allen, 2013; Oréal, 2014; Schenkel, 2012; Stauder, 2014a,b,c; Uljas, 2011 ), which contrasts to more lexical-unit and context-based studies such as one earlier attempt by Jean Winand (1991) on the verb il/iw 'come' to break through the graphemic opacity of the verbal forms, very much in the wake of the fundamental studies by De Cénival (1972, 1977).

\subsection{The document and its language}

The first of the shifts mentioned above pushed the research onto subjects that linked language and texts. This shift proceeded along with three trends: text grammar (or genre linguistics); text dating through linguistics; and the communicative aspects of the language.

Text grammar. The study of textual "genres" with a linguistic intent is not new in Egyptology (Hintze, 1950-1952; Junge, 1978) but has instead moved from more stylistically-based studies to more linguistically-based ones. Examples range from structuralist studies such as Díaz Hernández (2013), Marc Brose (2014) and Claudia Suhr (2016) with the intent to characterize a genre through morphosyntactic elements to the studies initiated by James P. Allen (2017) that focus on retrieving a whole grammar from different documents holding a (long enough) text like the Pyramid Texts - the first volume of the six planned works on the Pyramid of Unis has just appeared.

Text dating. Essential studies in historical grammar fostered the way to the possibility of dating texts through linguistic criteria. That is especially the case of studies that have focused on 'grams' (linguistic elements that take a role in grammatical changes, see Bybee, 1986) such as the auxiliary verb iri and the analytic trend in Later Egyptian (Loprieno, 1995, p. 90-91; Kruchten, 1999, p. 1-51), the passive affix/pronoun tw (Stauder 2014d; Vernus, 1998, p. 200-207), the specialization of $i w$ for circumstances (Kruchten, 1999, p. 52-85; Loprieno, 1995, p. 91 ; Vernus, 
1998, p. 194-197). This research line has produced some significant works on text dating in recent times, including Winand (1995), Stauder (2013b), and Moers (2013). Recent short introductions to Old Egyptian (Allen, 2015) and Late Egyptian (Winand, 2018) are available as well.

In addition to this, archaism, as an umbrella concept, has played a central role in the research about text dating and related topics (Der Manuelian, 1994; Engsheden, 2016; Gillen, 2017; Jansen-Winkeln, 1994, 1995; Stauder, 2013a; Vernus, 1996, 2016). In the heart of the risk for circularity, archaism evidences the weakness in dating a text through linguistic features when the features can be archaic in the first place, i.e. intentionally used by the writer to pretend an older date for the text, out of prestige, among other possible reasons.

Communicative aspects of language. Sociolinguistic approaches focusing on the speaker's communicative strategies and how these are rendered in the texts have appeared in recent years, some centred on specific types of texts such as Deborah Sweeney's (2001) and Kim Ridealgh's (2016) on Late Ramesside letters, and the collective volume on scribal practices edited by Jennifer Cromwell and Eitan Grossmann (2017) with contributions on Later Egyptian (Late Egyptian Demotic - Coptic). Other studies have in different degrees been concerned with semantic topics on occasions as well, but the primary attention has remained with the communicative aspects of the texts. That is the case of Mark Collier's fundamental study on the foreground/background Gestalt schema applied to the arranging of communication in ancient Egyptian (Collier, 1994), or more recently systematic studies on modality and subordinate clauses (Uljas, 2007), and pragmatic markers (Oréal, 2011).

\subsection{Bridging opposing terms (Dictionary versus Grammar)}

Semantic-oriented studies, i.e. those that face the problem of how form and meaning relate to each other in natural languages, are a minority in Egyptology when compared to syntactic and pragmatic studies. The piffalls are many: if grammatical morphology is obscure, lexical morphology is even darker, and there is no general agreement on the basic structure of the Egyptian word. Essential elements in lexical morphology such as 'root', or 'prefix' are far from finding common ground for explanation in the Egyptological literature, ranging from purely formalist approaches (Reintges, 1994) to convincedly comparatist approaches (Takács, 19992007), following a more-than-centenary research trend: e.g. Gaston Maspero (1881) and Theodor Benfey (1844), respectively. In between, the need for contextualized studies has been stated but also on different terms: on one side, lexicographical studies (Meeks 1999) on the other under the light of lexical semantics (Winand, 1994, 1999). The main difference of all these approaches is that while lexical semantics faces the form-meaning link by looking into the interaction between morphosyntax and the meaning (the semantic interface), the other approaches implicitly consider that lexicon is a passive repository of words which is acted (selected, transformed) by grammatical mechanisms (norms). Recent dictionaries such as the impressive piece of scholarship achieved by Rainer Hannig with his series of Lexica (1999a,b, 2000, 2003, 2006, fc.) still adopt this view, while the institutional project of the Berlin-Brandenburgische Akademie der Wissenschaften Thesaurus Linguae Aegyptiae (2014) is progressively implementing its update of the classic Wörterbuch der ägyptischen Sprache (1926-1963) with linguistic information.

In two recent talks, Jean Winand $(2012,2015)$ has claimed the necessity of international, collaborative initiatives to produce a new dictionary covering the needs not only of Egyptological 
(specialized and general) users but of (general and comparatist) linguists as well. This is not a desideratum for only a dictionary. Given the method and objective which is a stake, the desideratum is about a new approach to ancient Egyptian (or any other natural language) consisting in the combination of studying the semantic-syntactic interface through studies of large and coherent groups of words (onomasiological approaches) empirically and systematically analysed through gear-driven corpus-based methods (text mining).

A significant milestone in the study of the semantic-syntactic interface is Winand's study of temporality in ancient Egyptian (2006). For the first time, this work provides a comprehensive sight into the linguistic expression of verbal and non-verbal time in ancient Egyptian, displaying the complexities of the interaction between lexical time (Aktionsart) and structural time (morphosyntactic aspect-and-tense features) attuned with the long tradition of linguistic studies in one of the central topics in linguistic universals (from Reichenbach, 1947 and Vendler, 1957 to Binnick, 1991; Klein, 1994 and Bertinetto, 1997, among many others). Winand's study is not only for the benefit of the Egyptology to achieve a reliable understanding of linguistic phenomena unsatisfactorily understood until then (e.g. the reinterpretation of the verbs of quality as gradual accomplishments of implicit telicity) but of linguistics as well by having access to a wealth of linguistic phenomena that Egyptian is in an ideal position to provide given its longevity.

Similar works in range and scope are scheduled for publication in the series mentioned above The Mouton Companions to Ancient Egyptian: one monograph on the non-verbal predication has been recently published (Loprieno, Müller \& Uljas, 2017), and a comprehensive study on the negation is announced (Oréal and Winand, fc.).

In recent years, other works have furthered this research line of semantic-syntactic interaction that have dealt with verbal valency (Hafemann, 2001, 2006), lexical semantics (Gracia Zamacona $2015 a, b$; Vernus, 2012, 2015, 2019), grammaticalization processes linked to lexical semantics such as the future one (Grossmann, Lescuyer \& Polis 2014), or ib as a modal verb (Polis \& Stauder, 2014).

\subsection{Is ancient Egyptian our ancient Egyptian?}

A final even if short note must find its place here on the question of how are Egyptologists studying ancient Egyptian language and with what purpose.

Bernard Mathieu (2013) has drawn attention to some issues on ethnocentrism concerning how some linguistic terms have been used in studies on Ancient Egyptian (see already Eyre, 1991). Mathieu's remarks perfectly fit in the process of "epistemological distance" awareness which has grown in recent years in Egyptology (Gracia Zamacona, fc.; Moreno, 2014, 2015; Nyord, 2018, 2019; Schneider \& Raulwing, 2013; Vernus, 2013). In this vein, one should keep in mind as well the linguistic awareness ancient Egyptians might have had of their language (Uljas, 2013; see also Klotz, 2011; Kurth, 2011; Von Lieven, 2007).

An example of the more or less unconscious bias that can affect ancient Egyptian teaching is what can be named "The lure of translation": most classes are structured on decontextualised examples in ancient Egyptian, which the student is asked to translate and for which, too often univocal equivalences are proposed for the Egyptian words in the target language. Although not a method exclusive of the teaching of ancient Egyptian (which does not ease the pain), this method should 
be substituted by more hands-on systems whenever possible, such as working on real texts with more time, and in teamwork (knowing that this is often difficult to match with very busy curricula).

Last but not least, it should be the teacher's chief concern to tell the evidence from the hypothetical in the class to help the student find their way through the forest of theories and the cliffs of the texts.

\section{Conclusion}

How distance has grown from the sources and how decontextualised approaches have taken the lead is illustrated by Kristina Hutter's (2017) monograph on the verbal suffixal paradigm. Hutter devotes her study to analyse the verbal suffixal morphology exclusively from the grammar handbooks. This approach provides a picture of the Egyptological grammar "schools" the value of which for the history of the discipline is undeniable, but no information about the verbal suffixal forms in Middle Egyptian. It is relevant that fundamental articles on the empirical study of these forms in Middle Egyptian such as De Cénival $(1972,1977)$ and Winand $(1991)$, which are central to the matter under study, are not even quoted. A similar compiling study is Karsten Peust's (1999) about the studies on the phonology of ancient Egyptian.

To this absorbed Egyptology an empirically-based approach is profoundly wished and needed (Gracia Zamacona 2013): through the combination of exhaustive contextualised, empirical studies with multifactorial analyses to provide patterns that might be of relevance for the different linguistic spheres (phonologic, morphosyntactic, semantic and pragmatic), and their interactions.

The educational implications of the contributions which have been discussed in this article are as follows:

- one, to give a detailed picture of the difficulties in the structure, uses and study of the Egyptian language, and to avoid simplifications;

- two, to provide a precise idea of the difference between results proven and hypotheses emitted;

- three, to gain specific knowledge of the study methods in linguistics, and the possible research lines they allow to implement.

Corpus-based approaches lean on the empirical linguistic method of determining relevant patterns by using text mining quantitative techniques (Rosmorduc, 2015) such as corpus annotation and computational dispersion studies that are combined with flexible research lines to allow to study the interface between forms (morphosyntax) and functions (semantics and pragmatics). For this reason, they are the most promising approaches to improve our knowledge in the ancient Egyptian grammar and lexicon, then how to teach it, which has always been a constant preoccupation of the discipline (Depuydt, 1993; Junge, 1991; Schenkel, 1980; Winand, 2011). By proposing descriptions off case studies instead of illustrating theories with examples, empirically-based studies are bringing a new sight into the research and teaching of ancient Egyptian (see Fig. 1): 


\section{Examples}
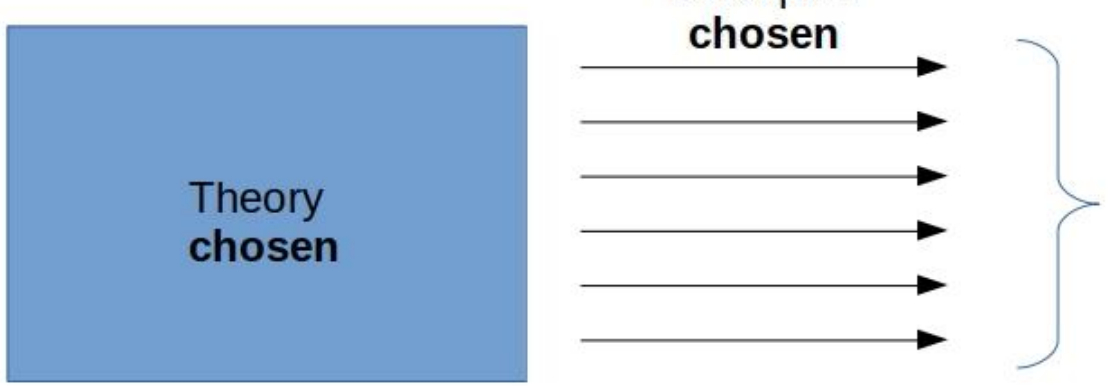

To illustrate the theory

\section{Cases}
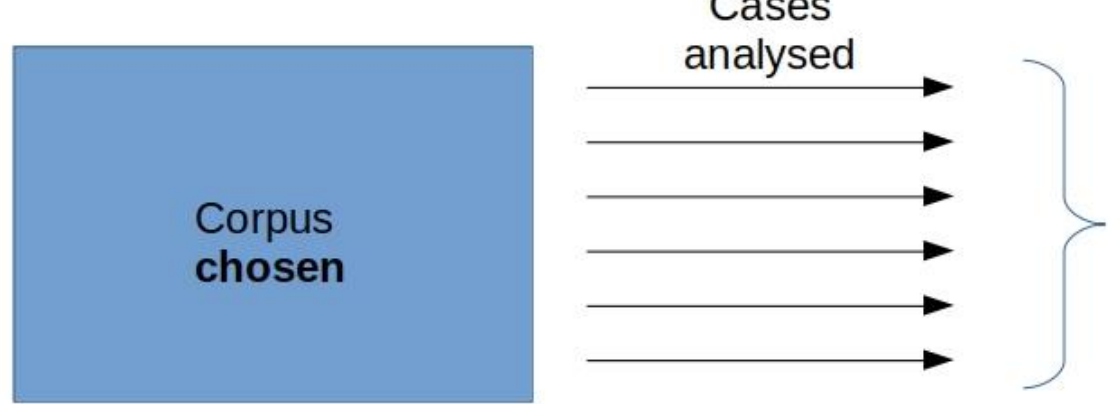

To create a description

Fig. 1. Illustration versus Description. Source: Author.

\section{Acknowledgements}

This paper has been written under the auspices of the Project The Earlier Ancient Egyptian Mortuary Texts Variability (2018-T1/HUM-10215 Talento Programme, funded by Madrid Region).

\section{Bibliography}

Allen, J. P. (2013). Middle Egyptian: An introduction to the language and culture of hieroglyphs (3rd edition). Cambridge: Cambridge University Press.

Allen, J. P. (2015). Old Egyptian. In Stauder-Porchet, J., Stauder, A. \& Wendrich, W. (eds.), UCLA Encyclopedia of Egyptology (pp. 1-11). Los Angeles: UCLA. Retrieved from: http://digital2.library.ucla.edu/viewltem.do?ark=21 198/zz002ii949

Allen, J. P. (2017). A grammar of the ancient Egyptian Pyramid Texts I: Unis. Eisenbrauns: University Park, PA.

Allen, J. P., Collier, M. A., \& Stauder, A. (eds.) (2016). Coping with obscurity: The Brown workshop on Earlier Egyptian grammar (Wilbour Studies in Egyptology and Assyriology, 3). Atlanta: Lockwood.

Arnold, M. (1869). Culture and Anarchy. London: Smith, Elder and Company.

Assmann, J. (1974). Ägyptologie und Linguistik. Göttinger Miszellen, 1 1, 59-76.

Austin, J. L. (1962). How to do things with words. Cambridge: Harvard University Press.

Benfey, Th. (1844). Ueber das Verhältniss der ägyptischen Sprache zum semitischen Sprachstamm. Leipzig: Brockhaus. 
Bertinetto, P. M. (1997). II dominio tempo-aspettuale: demarcazioni, sezioni, contrasti. Turin: Rosenberg \& Sallier.

Biber, D. (1989). A typology of English texts. Linguistics, 27, 3-43.

Binnick, R. I. (1991). Time and the verb: A guide to tense and aspect. Oxford: Oxford University Press.

Bybee, J. (1985). Morphology: A study of the relation between meaning and form. Amsterdam: Benjamins.

Bybee, J. L. (1986). On the nature of grammatical categories: A diachronic perspective. Eastern States Conference on Linguistics, 2, 17-34.

Bybee, J., Perkins, R. \& Pagliuca, W. (1994). The evolution of grammar: Tense, aspect and modality in the languages of the world. Chicago: University of Chicago Press.

Champollion, J.-F. (1829). Lettres de M. Champollion le jeune, écrites pendant son voyage en Égypte en 1828 et 1829 . Paris: Didot.

Clère, J. J. (1949). Une nouvelle forme verbale relative en égyptien. In Anonymous (ed.), $21^{\text {st }}$ Congress of Orientalists (pp. 64-66). Paris: Ed. Société Asiatique.

Collier, M. (1994). Grounding, cognition and metaphor in the grammar of Middle Egyptian. In F. Junge, F. Kammerzell \& A. Loprieno (eds.), Proceedings of the international conference on Egyptian grammar (Crossroads III), Yale, April 4-9, 1994 (Lingua Aegyptia, 4) (pp. 57-87). Göttingen: Ed. Seminar für Ägyptologie und Koptologie.

De Cénival, J. L. (1972). Sur la forme $s \underline{d} m$.f à redoublement ou mrr.f. Revue d'Égyptologie, 24, 40-45.

De Cénival, J. L. (1977). Les écritures du verbe $m 33$ "voir" dans les Textes des Sarcophages: Leurs conséquences théoriques. Revue d'Égyptologie, 29, 21-37.

Cromwell, J. and Grossman, E. (eds.) (2017). Scribal repertoires in Egypt from the New Kingdom to the Early Islamic Period. Oxford: Oxford University Press.

Depuydt, L. (1983). The Standard theory of the "emphatic" forms in Classical (Middle) Egyptian: a historical survey. Orientalia Lovaniensia Periodica, 14, 13-54.

Depuydt, L. (1993). A Note on learning and teaching Egyptian. Lingua Aegyptia, 3, 1-5.

Depuydt, L. (1994). A new generation of teaching grammar (1987-93). Orientalia Lovaniensia Periodica, 25, 275-276.

Depuydt, L. (1995). Sentence pattern and verb form: Egyptian grammar since Polotsky. Muséon, $108,39-48$.

Depuydt, L. (1996). Materials for Egyptian grammar: catalogue of coordinates and satellites of the Middle Egyptian verb. Leuven: Peeters.

Derrida, J. (1967). De la grammatologie. Paris: Minuit.

Díaz Hernández, R. (2013). Tradition und Innovation in der offiziellen Sprache des Mittleren Reichs: ein strukturalistischer Vergleich der historisch-biographischen mit den literarischen Texten der 1. Zwischenzeit und der 12. Dynastie (Göttinger Orientforschungen, 56). Wiesbaden: Harrassowitz. 
Edel, E. (1955-1964). Altägyptische Grammatik I-II (Analecta Orientalia, 34 and 39). Rome: Pontificium Institutum Biblicum.

Englund, G., \& J. Frandsen (eds.) (1986). Crossroad: Chaos or the beginning of a new paradigm; Papers from the conference on Egyptian grammar; Helsingor 28-30 May 1986 (CNI Publications, 1). Copenhague: Carsten Niebuhr Institute of Ancient Near East Studies.

Engsheden, Å. (2016). Traditional Egyptian II (Ptolemaic, Roman). In J. Stauder-Porchet, A. Stauder \& W. Wendrich (eds.), UCLA Encyclopedia of Egyptology (pp. 1-9). Los Angeles: Ed. UCLA. Retrieved from: http://digital2.library.ucla.edu/viewltem.do?ark $=21198 / \mathrm{zz002k6stb}$

Erman, A., \& H. Grapow (1926-1963). Wörterbuch der ägyptischen Sprache I-VII. Leipzig: Hinrichs.

Eyre, Ch. (1991). Was ancient Egyptian really a primitive language? In A. Loprieno (ed.), Proceedings of the second international conference on Egyptian grammar (Crossroads II); Los Angeles, October 17-20, 1990 (Lingua Aegyptia, 1) (pp. 97-123). Göttingen: Ed. Seminar für Ägyptologie und Koptologie.

Fecht, G. (1960). Wortakzent und Silbenstruktur: Untersuchungen zur Geschichte der ägyptischen Sprache (Ägyptologische Forschungen, 21). Glückstadt: Augustin.

Gardiner, A. H. (1951). The theory of speech and language. Oxford: Clarendon Press.

Gardiner, A. H. (1957). Egyptian grammar: Being an introduction to the study of hieroglyphs (3rd edition; $1^{\text {st }}$ published 1927). Oxford: Griffith Institute.

Gillen, T. (ed.) (2017). (Re)productive traditions in ancient Egypt: Proceedings of the conference held at the University of Liège, 6th-8th February 2013 (AEgyptiaca Leodiensia, 10). Liège: Presses Universitaires de Liège.

Golénischeff, W. (1922). Quelques remarques sur la syntaxe égyptienne. In Anonymous (ed.), Recueil d'études égyptologiques: Dédiées à la mémoire de Jean-François Champollion à l'occasion du centenaire de la lettre à $M$. Dacier relative à l'alphabet des hiéroglyphes phonétiques, lue à l'Académie des inscriptions et belles-lettres le 27 septembre 1822 (pp. 685$711)$. Paris: Ed. Édouard Champion.

Gracia Zamacona, C. (fc.). (In(ter))discipline: The case of Egyptology. (30 pages).

Gracia Zamacona, C. (2015a). Tests on verbal Aktionsart applied to Ancient Egyptian: instruments to determine verbal semantics in an ancient language. Afrikanistik und Aegyptologie Online. Retrieved from https://www.afrikanistik-aegyptologie-online.de/archiv/2015).

Gracia Zamacona, C. (2015b). $A$ ' $q$ 'enter', but how, and where? Data from the Coffin Texts. Antiguo Oriente, 13, 41-82.

Gracia Zamacona, C. (2013). A database for the Coffin Texts. In S. Polis \& J. Winand (eds.), Texts, languages and information technology in Egyptology (Aegyptiaca Leodiensia 9) (pp. 139-155). Liège: Presses Universitaires de Liège.

Grossman, E., Haspelmath, M. \& Richter, T.S. (eds.) (2015). Egyptian-Coptic linguistics in typological perspective (Empirical Approaches to Language Typology, 55). Berlin: De Gruyter Moton.

Grossman, E., Lescuyer, G. \& Polis, St. (2014). Contexts and inferences: The grammaticalization of the Later Egyptian Allative Future. In E. Grossman, S. Polis, A. Stauder \& J. Winand (eds.), 
On forms and functions: Studies in ancient Egyptian grammar (Lingua Aegyptia - Studia Monographica, 15) (pp. 87-136). Hamburg: Widmaier.

Grossman, E., Polis, S. \& Winand, J. (eds.) (2012). Lexical semantics in ancient Egyptian (Lingua Aegyptia - Studia Monographica, 9). Hamburg: Widmaier.

Grossman, E., Polis, St., Stauder, A. \& Winand, J. (eds.) (2014). On forms and functions: Studies in ancient Egyptian grammar (Lingua Aegyptia - Studia Monographica, 15). Hamburg: Widmaier.

Gunn, B. (1924). Studies in Egyptian syntax. Paris: Geuthner.

Hafemann, I. (2001). Zum Zusammenspiel von Semantik und Syntax ägyptischer Verben. Lingua Aegyptia, 10, 151-210.

Hafemann, I. (2006). Lexikon und Argumentstruktur. Lingua Aegyptia, 14, 349-374.

Hagège, C. (1996). L'homme de paroles: Contribution linguistique aux sciences humaines. Paris: Fayard.

Hannig, R. (1999a). Die Sprache der Pharaonen: Großes Handwörterbuch Ägyptisch-Deutsch (2800 bis 950 v. Chr.) (Hannig-Lexica, 1; Kulturgeschichte der antiken Welt, 64). Mainz: Zabern.

Hannig, R., \& Vomberg, P. (1999b). Kulturhandbuch Ägyptens: Wortschatz der Pharaonen in Sachgruppen (Hannig-Lexica, 2; Kulturgeschichte der antiken Welt, 72). Mainz: Zabern.

Hannig, R. (2000). Die Sprache der Pharaonen: Großes Handwörterbuch Deutsch-Ägyptisch (2800 bis 950 v. Chr.) (Hannig-Lexica, 3; Kulturgeschichte der antiken Welt, 86). Mainz: Zabern.

Hannig, R. (2003). Ägyptisches Wörterbuch I: Altes Reich und erste Zwischenzeit (Hannig-Lexica, 4; Kulturgeschichte der antiken Welt, 98). Mainz: Zabern.

Hannig, R. (2006). Ägyptisches Wörterbuch II: Mittleres Reich und Zweite Zwischenzeit (HannigLexica, 5; Kulturgeschichte der antiken Welt, 112 ). Mainz: Zabern.

Hannig, R. (fc.). Ägyptisches Wörterbuch III: Neues Reich (Hannig-Lexica, 6). Mainz: Zabern.

Hintze, F. (1950, 1952). Untersuchungen zu Still und Sprache Neuägyptischer Erzählungen (Veröffentlichungen des Instituts für Orientforschung, 2 and 6). Berlin: Akademie.

Jansen-Winkeln, K. (1994). Text und Sprache in der 3. Zwischenzeit: Vorarbeiten zu einer spätmittelägyptischen Grammatik (Ägypten und Altes Testament, 26). Wiesbaden: Harrassowitz.

Jansen-Winkeln, K. (1995). Diglossie und Zweisprachigkeit im alten Ägypten. Wiener Zeitschrift für die Kunde des Morgenlandes, 85, 85-115.

Junge, F. (1978). Syntax der mittelägyptische Literatursprache. Mainz: Zabern.

Junge, F. (1989). "Emphasis" and sentential meaning in Middle Egyptian (Göttinger Orientforschungen, IV/20). Wiesbaden: Harrassowitz.

Junge, F. (1991). How to study Egyptian grammar and to what purpose: A summary of sorts. In Loprieno, A. (ed.), Proceedings of the Second International Conference on Egyptian Grammar (Crossroads II) Los Angeles, October 17-20, 1990 (Lingua Aegyptia, 1) (pp. 389-426). Göttingen: Ed. Seminar für Ägyptologie und Koptologie. 
Junge, F., Kammerzell, F. \& Loprieno, A. (eds.) (1994). Proceedings of the third international conference on Egyptian grammar (Crossroads III); Yale, April 4-9, 1994 (Lingua Aegyptia, 4). Göttingen: Seminar für Ägyptologie und Koptologie.

Klein, W. (1994). Time in language. London: Routledge.

Klotz, D. (2011). A new edition of the "Book of Nut". Bibliotheca Orientalis, 65, 476-491.

Kruchten, J.M. (1999). From Middle Egyptian to Late Egyptian. Lingua Aegyptia, 6, 1-97.

Kurth, D. (201 1). Zur Definition des Ptolemäischen. Göttinger Miszellen, 229, 65-80.

Lepper, V. (ed.) (2006). After Polotsky: New research and trends in Egyptian and Coptic linguistics (Lingua Aegyptia, 14). Göttingen: Seminar für Ägyptologie und Koptologie.

Von Lieven, A. (2007). Grundriss des Laufes der Sterne: Das Sogenannte Nutbuch (The Carlsberg Papyri, 8; Carsten Niebuhr Institute Publications, 31 ). Copenhagen: Museum Tusculanum Press.

Loprieno, A. (1986). Das Verbalsystem im Ägyptischen und im Semitischen: Zur Grundlegung einer Aspekttheorie (Göttinger Orientforschungen, IV/17). Wiesbaden: Harrassowitz.

Loprieno, A. (ed.). (1991). Proceedings of the second international conference on Egyptian grammar (Crossroads II): Los Angeles, October 17-20, 1990. (Lingua Aegyptia 1). Göttingen: Seminar für Ägyptologie und Koptologie. Retrieved from: http://wwwuser.gwdg.de/ lingaeg/lingaeg01.htm

Loprieno, A. (1994). As a Summary: New tendencies in Egyptological Linguistics. In F. Junge, F. Kammerzell \& A. Loprieno (eds.), Proceedings of the international conference on Egyptian grammar (Crossroads III) Yale, April 4-9, 1994 (Lingua Aegyptia, 4) (pp. 369-382). Göttingen: Ed. Seminar für Ägyptologie und Koptologie.

Loprieno, A. (1995). Ancient Egyptian: A linguistic introduction. Cambridge: Cambridge University Press.

Loprieno, A. (2003). Egyptian linguistics in the year 2000. In Z. Hawass (ed.), Egyptology at the dawn of the twenty-first century: Proceedings of the eighth International Congress of Egyptologists I-III (vol. III, pp. 73-94). Cairo: Ed. American University in Cairo Press.

Loprieno, A., Müller, M. \& Ulias, S. (2017). Non-Verbal Predication in ancient Egyptian (The Mouton Companions to Ancient Egyptian, 2). Berlin: De Gruyter.

Der Manuelian, P. (1994). Living in the past: Studies in archaism of the Egyptian twenty-sixth dynasty. London: Kegan Paul International.

Maspero, G. (1881). Sur la formation des thèmes trilitères en égyptien. Mémoires de la Société Linguistique de Paris, 4, 185-203.

Mathieu, B. (2013). Grammaire et politique: Réflexions sur quelques empreintes idéologiques dans la terminologie linguistique des grammaires de l'égyptien ancien. In S. Bickel, H. W. FischerElfert, A. Loprieno \& S. Richter (eds.), Ägyptologen und Ägyptologien zwischen Kaiserreich und Gründung der beiden deutschen Staaten: Reflexionen zur Geschichte und Episteme eines altertumswissenschaftlichen Fachs im 150. Jahr der Zeitschrift für Ägyptische Sprache und Altertumskunde (Zeitschrift für ägyptische Sprache und Altertumskunde Beiheft, 1) (pp. 437 456). Berlin: Ed. De Gruyter. 
Meeks, D. (1999). Dictionnaires et lexicographie de l'égyptien ancien: Méthodes et résultats. Bibliotheca Orientalis, 56, 569-594.

Moers, G., Widmaier, K., Giewekemeyer, A., Lümers A. \& Ernst, R. (eds.) (2013). Dating Egyptian literary texts (Lingua Aegyptia - Studia Monographica 11). Hamburg: Widmaier.

Moreno García, J. C. (2014). The Cursed discipline? The peculiarities of Egyptology at the turn of the twenty-first century. In W. Carruthers (ed.), Histories of Egyptology: Interdisciplinary Measures (Routledge Studies in Egyptology, 2) (pp. 50-63). New York: Ed. Routledge.

Moreno García, J. C. (2015). Un mito tenaz: el Egipto antiguo o el paraíso perdido en la obra de los egiptólogos de finales del siglo XIX y comienzos del siglo XX. In R. Da Riva \& J. Vidal (eds.), Descubriendo el antiguo oriente: pioneros y arqueólogos de Mesopotamia y Egipto a finales del siglo XIX y principios del siglo XX (pp. 103-122). Barcelona: Bellaterra.

Müller, M., \& Uljas, S. (eds.) (2009). Proceedings of the fourth international conference on Egyptian grammar (Crossroads IV) Basel, March 19-22, 2009 (Lingua Aegyptia, 17). Göttingen: Seminar für Ägyptologie und Koptologie.

Nyord, R. (2015). Cognitive Linguistics. In J. Stauder-Porchet, A. Stauder \& W. Wendrich. (eds.), UCLA Encyclopedia of Egyptology (pp. 1-11). Los Angeles: Ed. UCLA. Retrieved from: http://digital2.library.ucla.edu/viewltem.do?ark $=21$ 198/zz002k44p6

Nyord, R. (2018). "Taking ancient Egyptian mortuary religion seriously": Why would we, and how could we? Journal of Ancient Egyptian Interconnections, 17, 73-87.

Nyord, R. (ed.). (2019). Concepts in Middle Kingdom Funerary Culture: Proceedings of the Lady Wallis Budge Anniversary Symposium Held at Christ's College, Cambridge, 22 January 2016 (Culture and History of the Ancient Near East, 102). Leiden: Brill.

Oréal, E. (1999). Contact linguistique: le cas du rapport entre le grec et le copte. Lalies, 19, 289306.

Oréal, E. (2011). Les particules en égyptien ancien: De l'ancien égyptien à l'égyptien classique (Bibliothèque d'Égyptologie, 152). Cairo: Institut Français d'Archéologie Orientale.

Oréal, E. (2014). Noun phrase syntax and definiteness marking: A new explanation for the morphology of Earlier Egyptian participles. In E. Grossman, S. Polis, A. Stauder \& J. Winand (eds.), On forms and functions: Studies in ancient Egyptian grammar (Lingua Aegyptia - Studia Monographica, 1) (pp. 173-200). Hamburg: Ed. Widmaier.

Oréal, E., \& Winand, J. (fc.). Negation in Ancient Egyptian (The Mouton Companions to Ancient Egyptian, 3). Berlin: De Gruyter.

Peust, C. (1999). Egyptian phonology: An introduction to the phonology of a dead language. Göttingen: Peust \& Gutschmidt.

Polis, S. \& Stauder, A. (2014). The verb $\mathrm{ib}$ and the Construction $\mathrm{ib}=\mathrm{f} \mathrm{r}$ sDm: On modal semantics, graphemic contrasts, and gradience in grammar. In E. Grossman, S. Polis, A. Stauder \& J. Winand (eds.), On forms and functions: Studies in ancient Egyptian grammar (Lingua Aegyptia - Studia Monographica, 1) (pp. 201-231). Hamburg: Ed. Widmaier.

Polotsky, H. J. (1944). Études de syntaxe copte. Le Caire: Institut Français d'Archéologie Orientale.

Polotsky, H. J. (1965). Egyptian tenses. Israel Academy of Sciences and Humanities Proceedings, $2 / 5,1-25$. 
Polotsky, H. J. (1976). Les transpositions du verbe en égyptien classique. Israel Oriental Studies, 6, $1-50$.

Polotsky, H .J. (1987). Egyptology, Coptic studies and the Egyptian language. In J. Ray (ed.), Lingua sapientissima: A seminar in honour of H. J. Polotsky (pp. 5-21). Cambridge: Faculty of Oriental Studies.

Reichenbach, H. (1947). Elements of symbolic logic. London: Collier-MacMillan.

Reintges, Ch. (1994). Egyptian root-and-pattern morphology. In F. Junge, F. Kammerzell \& A. Loprieno (eds.) (1994). Proceedings of the third international conference on Egyptian grammar (Crossroads III); Yale, April 4-9, 1994 (Lingua Aegyptia, 4) (pp. 213-244). Göttingen: Ed. Seminar für Ägyptologie und Koptologie.

Reintges, Ch. (1997). Passive voice in Older Egyptian: A morpho-syntactic study (HIL Dissertations, 28). The Hague: Holland Institute of Generative Linguistics.

Ridealgh, K. (2016). Polite like an Egyptian? Case studies of 'politeness' in the Late Ramesside letters. Journal of Politeness Research, 12(2), 245-266.

Rosmorduc, S. (2015). Computational Linguistics in Egyptology. In J. Stauder-Porchet, A. Stauder \& W. Wendrich (eds.), UCLA Encyclopedia of Egyptology (pp. 1-12). Los Angeles: UCLA. Retrieved from: http://digital2.library.ucla.edu/viewltem.do?ark=21 198/zz002hh4wt

Satzinger, H. \& Shisha-Halevy, A. (1999). The Snark is dead (Pascal Vernus, Les parties du discours en Moyen Égyptien. Autopsie d'une théorie). Lingua Aegyptia, 6, 167-176.

De Saussure, F. (1916). Cours de linguistique générale. Lausanne and Paris: Payot.

Schenkel, W. (1980). Thesen zum ägyptischen Sprachunterricht. Göttinger Miszellen, 40, 81-97.

Schenkel, W. (1988). Aktuelle Perspektiven der ägyptischen Grammatik. Bibliotheca Orientalis, 45, 269-289.

Schenkel, W. (1991). Tübinger Einführung in die klassisch-ägyptische Sprache und Schrift. Tübingen: pagina.

Schenkel, W. (2012). Da capo: Zur Formenbildung des Präteritums $s \underline{d} m=f / r \underline{d} i=f$ der Verben Il.red. Göttinger Miszellen, 233, 69-74.

Schneider, Th., \& Raulwing, P. (eds.) (2013). Egyptology from the First World War to the Third Reich: Ideology, scholarship and individual biographies. Leiden: Brill.

Sweeney, D. (2001). Correspondence and dialogue: Pragmatic features in Late Ramesside letterwriting (Ägypten und Altes Testament, 49). Harrassowitz: Wiesbaden.

Shisha-Halevy, A. (2007). Topics in Coptic syntax: Structural studies in the Bohairic dialect (Orientalia Lovaniensia Analecta, 160). Leuven: Peeters.

Stauder, A. (2013a). L'émulation du passé à l'ère thoutmoside: la dimension linguistique. In Bickel, S. (ed.), Vergangenheit und Zukunft: Studien zum historischen Bewusstsein in der Thutmosidenzeit (Aegyptiaca Helvetica, 22) (pp. 77-125). Basel: Ed. Schwabe.

Stauder, A. (2013b). Linguistic dating of Middle Egyptian literary texts (Lingua Aegyptia - Studia Monographica, 12). Hamburg: Widmaier. 
Stauder, A. (2014a). Splitting the $s d m . n=f ?$. A discussion of written forms in Coffin Texts. Zeitschrift für Ägyptische Sprache, 1 41, 83-96.

Stauder, A. (2014b). Splitting the $s \underline{d} . n=f ?$ ? A discussion of written forms in Coffin Texts. Zeitschrift für Ägyptische Sprache, 141, 195-208.

Stauder, A. (2014c). Interpreting written morphology: the $s \underline{d m .} n=f$ in the Pyramid Texts. Journal of Near Eastern Studies, 73, 253-271.

Stauder, A. (2014d). The earlier Egyptian passive: voice and perspective (Lingua Aegyptia - Studia Monographica, 14). Hamburg: Widmaier.

Suhr, C. (2016). Die ägyptische "Ich-Erzählung": Eine narratologische Untersuchung (Göttinger Orientforschungen - Ägypten, 61). Wiesbaden: Harrassowitz.

Takács, G. (1999-2007). Etymological dictionary of Egyptian I-III (Handbook of Oriental Studies, 48). Brill: Leiden.

Thesaurus Linguae Aegyptiae (2014). Retrieved from: http://aaew.bbaw.de/tla/index.html

Thornton, B. (2002). Greek ways: How the Greeks created western civilization. London: Encounter.

Traugott, E. C., \& Heine, B. (eds.) (1991). Approaches to grammaticalization I-II. Amsterdam: Benjamins.

Uljas, S. (2007). The modal system of earlier Egyptian complement clauses: A study in pragmatics in a dead language (Probleme der Ägyptologie, 26). Leiden: Brill.

Uljas, S. (2011). Syncretism and the Earlier Egyptian $s d m=f$ : Speculations on morphological interconnections across paradigms. Lingua Aegyptia, 19, 155-174.

Uljas, S. (2013). Linguistic Consciousness. In Stauder-Porchet, J., Stauder, A. and Wendrich, W. (eds.), UCLA Encyclopedia of Egyptology (pp. 1-11). Los Angeles: UCLA. Retrieved from: http://digital2.library.ucla.edu/viewltem.do? ark $=21198 / \mathrm{zz} 002 \mathrm{dn} 8 \mathrm{xd}$

Vendler, Z. (1957). Verbs and times. Philosophical Review, 66, 143-160.

Vernus, P. (1990). Future at issue: Tense, mood and aspect in Middle Egyptian; studies in syntax and semantics (Yale Egyptological Studies, 4). New Haven: Yale Egyptological Seminar.

Vernus, P. (1996). Langue littéraire et diglossie. In A. Loprieno (ed.), Ancient Egyptian literature: History and forms (Probleme der Ägyptologie, 10) (pp. 559-564). Leiden: Ed. Brill.

Vernus, P. (1997). Les parties du discours en moyen égyptien: Autopsie d'une théorie (Cahiers de la Société d'Égyptologie, 5). Geneva: Société d'Égyptologie de Genève.

Vernus, P. (1998). Processus de grammaticalisation dans la langue égyptienne. Comptes Rendus des Séances de l'Académie des Inscriptions et Belles-Lettres, 142, 191-210.

Vernus, P. (2012). Le verbe $g m(j)$ : Essai de sémantique lexicale. In E. Grossman, S. Polis \& J. Winand (eds.), Lexical Semantics in Ancient Egyptian (Lingua Aegyptia - Studia Monographica, 9) (pp. 387-438). Hamburg: Widmaier.

Vernus, P. (2013). Égyptologie: Une discipline aux prises avec l'exceptionnelle valorisation sociétale de son objet. In S. Bickel, H. W. Fischer-Elfert, A. Loprieno \& S. Richter (eds.), Ägyptologen und Ägyptologien zwischen Kaiserreich und Gründung der beiden deutschen Staaten: Reflexionen zur Geschichte und Episteme eines altertumswissenschaftlichen Fachs im 
150. Jahr der Zeitschrift für Ägyptische Sprache und Altertumskunde (Zeitschrift für ägyptische Sprache und Altertumskunde Beiheft, 1) (pp. 457-480). Berlin: Ed. De Gruyter.

Vernus, P. (2015). ngmgm/gmgm sur la racine $\operatorname{Vgm}(1)$, "prendre contact, rencontrer, trouver". In R. Nyord \& K. Ryholt (eds.), Lotus and laurel: Studies on Egyptian language and religion in honour of Paul John Frandsen (pp. 419-430). Copenhagen: Museum Tusculanum Press.

Vernus, P. (2016). Traditional Egyptian I (Dynamics). In J. Stauder-Porchet, A. Stauder \& W. Wendrich (eds.), UCLA Encyclopedia of Egyptology (pp. 1-24). Los Angeles: UCLA. Retrieved from: http://digital2.library.ucla.edu/viewltem.do?ark=21 198/zz002k6th5

Vernus, P. (2019). Euphémisme métonymique ou euphémisme par antiphrase dans l'inscription d'Ourrê(/Rêour): Le verbe hsf et l'ambigüité vectorielle - ablatif ou allatif- de la préposition $r$. Göttinger Miszellen, 258, 129-150.

Werning, D. A. (ed.). (2017). Proceedings of the fifth international conference on Egyptian grammar (Crossroads V) Berlin, February 17-20, 2016 (Lingua Aegyptia, 25). Hamburg: Widmaier.

Whitmarsh, T., \& Thomson, S. (2013). The romance between Greece and the East. Cambridge: Cambridge University Press.

Winand, J. (1991). Le verbe iy/iw: Unité morphologique et sémantique. In Loprieno, A. (ed.), Proceedings of the Second International Conference on Egyptian Grammar (Crossroads II), Los Angeles, October 17-20, 1990 (Lingua Aegyptia, 1) (pp. 357-387). Göttingen: Ed. Seminar für Ägyptologie und Koptologie.

Winand, J. (1994). Entre sémantique et syntaxe: Pour une classification des lexèmes verbaux en néo-égyptien. In F. Junge, F. Kammerzell \& A. Loprieno (eds.), Proceedings of the third international conference on Egyptian grammar (Crossroads III); Yale, April 4-9, 1994 (Lingua Aegyptia, 4) (pp. 349-367). Göttingen: Ed. Seminar für Ägyptologie und Koptologie.

Winand, J. (1995). La grammaire au secours de la datation des textes. Revue d'Égyptologie, 46, 187-202.

Winand, J. (1999). Un dictionnaire des verbes néo-égyptiens. In Grunert, S. and Hafemann, I. (eds.), Textcorpus und Wörterbuch: Aspekte zur ägyptischen Lexikographie (Probleme der Ägyptologie, 14) (pp. 259-270). Leiden: Brill.

Winand, J. (2006). Temps et aspect en égyptien : Une approche sémantique (Probleme der Ägyptologie, 25). Leiden: Brill.

Winand, J. (2011). Teaching ancient Egyptian: Between linguistics and philology. In Verbovsek, A., Backes, B. and Jones, C. (eds.), Methodik und Didaktik in der Ägyptologie: Herausforderungen eines kulturwissenschaftlichen Paradigmenwechsels in den Altertumswissenschaften (Ägyptologie und Kulturwissenschaft, 4) (pp. 173-184). München: Fink.

Winand, J. (2012). A dictionary, please! The Leipzig call (30/11/2012). In Das Altägyptische Wörterbuch und die Lexikographie der ägyptisch-Koptsichen Sprache, 29-30 novembre 2012. Leipzig: Sächsische Akademie der Wissenschaften zu Leipzig. Retrieved from: https://orbi.uliege.be/handle/2268/134167

Winand, J. (2015). A new dictionary of Ancient Egyptian (27/08/2015). In The Eleventh International Association of Egyptologists Congress. Florence. Retrieved from: https://www.academia.edu/15421103/A new dictionary of Ancient Egyptian 
Winand, J. (2018). Late Egyptian. In Stauder-Porchet, J., Stauder, A. and Wendrich, W. (eds.), UCLA Encyclopedia of Egyptology (pp. 1-30). Los Angeles: UCLA. Retrieved from: http://digital2.library.ucla.edu/viewltem.do?ark=21 198/zz002kdgii

Wittgenstein, L. (1953). Philosophical investigations. London: Macmillan. 


\section{Panta Rei}

PANTA REl es una revista digital de investigación orientada a la Historia y la Didáctica de la Historia. Su principal objetivo es la transmisión del conocimiento científico, dando una oportunidad también a los jóvenes investigadores que quieren abrirse camino en el estudio de las ciencias humanas y sociales. Se compone de estudios originales relacionados con la disciplina histórica así como su didáctica y difusión. Las diferentes secciones que componen la revista son: artículos de investigación, entrevistas a profesionales, recensiones de monografías de actualidad y crónicas de congresos o eventos científicos relevantes.

Todos los artículos publicados son objeto de un proceso de revisión a cargo de un mínimo de dos evaluadores, que se consideran expertos en el ámbito temático del artículo propuesto. Nuestro deseo es poder ofrecer unos contenidos rigurosos, de calidad y de interés.

El CEPOAT (Centro de Estudios del Próximo Oriente y la Antigüedad Tardía de la Universidad de Murcia) es la institución encargada de la coordinación y gestión de la revista, desde donde anualmente se lanzará la convocatoria para aquellos que estén interesados en publicar sus trabajos, siempre relacionados con la Historia y la Didáctica de la Historia.

PANTA REI is a digital journal focused on History and Teaching History. Its main objective is the transmission of scientific knowledge by giving also an opportunity to young researchers who want to make their way in the study of human and social sciences. It is composed by original studies related to History, as well as its didactics and promotion. The different sections of this journal are: research articles, interviews to professionals, recensions on monographs about current issues and reports about congresses or relevant scientific events.

All the articles published are subject to a revision process carried out by a minimum of two reviewers who are considered to be experts in the field of the article proposed. Our wish is to offer rigorous contents with quality and being of interest to the reader.

CEPOAT (Centre of Studies of the Middle East and Late Antiquity of the University of Murcia) is the institution in charge of the coordination and management of this journal. This is the centre from where the call for papers will be launched annually for all the people interested in publishing their papers, always related to History and Teaching History. 


\section{Normas de publicación}

El autor se compromete a enviar trabajos originales, que no se encuentren publicados en otras revistas ni en otros idiomas. Así mismo, el mismo artículo no podrá ser presentado en otras revistas mientras dure el proceso de evaluación.

\section{Envío y presentación de originales}

Las normas de edición y forma de envío de artículos a la revista se pueden consultar en https://revistas.um.es/pantarei/

Para la redacción de los trabajos se tendrá en cuenta el Manual de la American Psychological Association, en su $7 .^{a}$ edición. La extensión máxima de los trabajos será de 25 páginas. La revista acepta originales escritos en español o inglés.

\section{Proceso de valoración y evaluación}

Una vez recibidos los trabajos, la Revista realizará una primera valoración. Si el trabajo enviado se ajusta a las normas de presentación propuestas, la temática es coincidente con la línea editorial de la revista y posee la calidad científica necesaria, será remitido al consejo asesor para una primera evaluación. Si no es así en este primer paso se puede rechazar directamente los documentos que incumplan claramente la línea editorial.

Será el Consejo Asesor quien indique a la revista la originalidad, relevancia, estructura, redacción, aparato bibliográfico, etc. del trabajo enviado y, para ello, se designará a dos revisores expertos externos que evaluarán cada uno de los trabajos, que pueden formar parte (o no) de este Consejo Asesor. La selección de los revisores se ajustará a la temática y características metodológicas del trabajo. El nombre y filiación de los autores serán eliminados del trabajo para su revisión, así como los revisores actuarán de manera anónima y confidencial.

Los revisores deberán rellenar un informe de evaluación que centrará su atención en aspectos tales como características formales, originalidad y novedad de los trabajos, relevancia de las propuestas y los resultados, calidad metodológica y validez científica.

Una vez terminado el proceso se decidirá la aceptación o no de los mismos y su publicación en el número que sea pertinente, así como las modificaciones susceptibles de ser realizadas para su final publicación. Dicha notificación se enviará únicamente por correo electrónico, en un plazo máximo de seis meses. 


\section{Publishing rules}

The author is committed to submit original papers not having been published in other reviews or in other languages. In this way, it is not allowed for the same paper to be presented in other reviews during the evaluation process.

\section{Submission and presentation of originals}

The editing rules and the guidelines for the submission of papers can be consulted at https://revistas.um.es/pantarei/

The seventh edition of the Manual of the American Psychological Association will be taken into account for the writing of the papers. The length of the submitted papers will not exceed the 25 pages. The journal accepts originals written in Spanish or English.

\section{Examination and assessment process}

The Journal will submit the papers to a first examination once received. If the paper follows the presentation guidelines, the subject agrees with the editorial line of this journal, and possess the scientific quality required, it will be sent to the advisory council for a first assessment. If not, the documents which clearly fail to complete the editorial line may be rejected straightaway in this first step.

The Advisory Council will indicate the originality, relevance, structure, writing, bibliography, etc. of the text to the journal; for this purpose, two outside experts will be designated to review the papers; these experts can be (or not) part of this Advisory Council. The selection of the experts will adjust to the subject and methodological characteristics of the paper. Name and affiliation of the author will be eliminated from the text for its review, in this way experts will act anonymously and confidentially.

The experts will fill out an assessment report which will focus on aspects such as formal characteristics, originality and novelty of the papers, relevance and results of the proposal, methodological quality and scientific validity.

Once the process is finished, the acceptance or not of the papers and its publication in the corresponding edition will be decided, as well as the modifications that may be done for its final publication. This notification will be sent by email within 6 months maximum. 


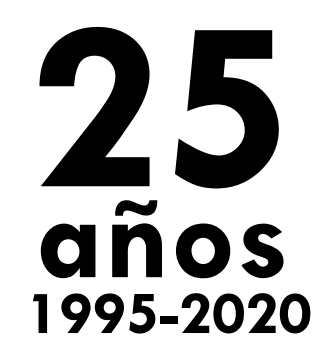

\section{cepoAt editum}

